\author{
Abner Nyamende The conception and application \\ Abner Nyamende is a Senior Lecturer \\ in the Department of African \\ Languages, University of Cape Town. \\ His most recent publication is Isaac \\ Williams Wauchope: Selected writings \\ 1874-1916 (Van Riebeeck Society, 2008). \\ E-mail: abner.nyamende@uct.ac.za

\section{of justice in S. E. K. Mqhayi's Ityala Lamawele}

\title{
The conception and application of justice in S. E. K. Mqhayi's Ityala Lamawele
}

There are many ways in which the Xhosa traditional manner of litigation is similar to the western way. There are also ways in which it is different. This article sets out to demonstrate those similarities and differences. In all this the common factor is that both the traditional Xhosa court and the western court as we know it strive to find the truth and to make the judgement as objective as possible. It is evident that Mqhayi was inspired by a biblical text, Genesis 38:27-30 to write a story where the Xhosa custom of finger cutting creates a legal complication. This paper also sets out to illustrate the wisdom of the Xhosa people in their interpretation of the law. The whole story in Mqhayi's novel is about this court trial and it functions as a brilliant exposition of the Xhosa legal system. Key words: Ityala lamawele (novella), S. E. K. Mghayi, traditional Xhosa court, Xhosa literature.

\section{Introduction}

S. E. K.Mqhayi's novel, Ityala lamawele ('The lawsuit of the twins'), gives us a clue to the nature and application of justice by the Xhosa people before their encounter with western culture. Educated at Lovedale, Mqhayi (1875-1945) is one of the early Xhosa Christians. Neethling and Mpolweni (2006:132) maintain that, "Unlike many others [...] [Mqhayi] never turned his back on his own culture." Many writers give different explanations of the reasons for Mqhayi to write this novelette. Soga (1930: 184) says that Mqhayi, "in his valuable treatise on The Case of the Twins (Ityala Lama Wele), gives a description of the methods and customs observed by the Courts of the Gcalekas with regard to any Fingo who was ill-treated in Hintsa's country." In this way Soga suggests that Hintsa and his people used justice to protect the Mfengu people. It is, however, not clear whether the Nzotho people were Gcaleka or Mfengu. E. D. and Marjorie Jones (2002: 37) maintain that Mqhayi's Ityala lamawele" concentrates mainly on important aspects of African tradition and custom." Thus though Mqhayi was a Christian, he hoped to demonstrate the virtues of African tradition and custom. Encyclopaedia Britannica holds that Ityala lamawele "is a defense of Xhosa law before European administration." B. W. Andrzejewski, S. Palaszewicz and W. Tyloch (1985: 600) state that Ityala lamawele was used by Mqhayi to defend "traditional Xhosa forms of justice against denigrations by South African whites." 
As the title of this novelette suggests, the whole story is about the court trial of the twins. While studying the conception of the case by the Xhosa people it will be important to also focus on the universality of human legal systems. This article is actually intended to revisit western thinking which often assumes that, "What is Western becomes universal and what is Third World becomes local," to put it in the language of Ngũgĩ wa Thiong'o (1993: 25). The article is also intended to define the Xhosa view of justice as a source of universal knowledge and, to follow Ngũgís observation, to illustrate that, "The universal is contained in the particular just as the particular is contained in the universal." (1993: 26).

The twins, Wele and Babini, are involved in a lengthy and bitter dispute over succession to their father's estate. What complicates the issue is that they are twins, which means that they have been born on the same day. Highlighting this point Dalthone (1974/1975: 44) comments thus:

Mqhayi makes the "case" even more difficult by presenting the contestants as twins. Who could claim to be different? His story, ostensibly about the right to rule, concerns the dubious assertion of individuality. The mere fact that they are twins not only heightens their similarity, but makes their case for separate recognition futile and ridiculous.

Ntuli and Swanepoel (1993: 31) see the story as, "a classical novel based on civil justice among the Xhosa, exemplified by the dispute between male twins over who, as the elder, was entitled to their father's inheritance." On their birth their mother experiences complications, when one baby's hand comes out first. Immediately one of the midwives cuts one of the unborn baby's fingers thereby performing the custom of ingqithi (the ritual cutting of a finger). Soon the hand withdraws and the baby who is born subsequently is in possession of all his fingers. Hours later the baby with a cut finger is also born. This sparks off a dispute among the midwives. Teyase, the chief witness in court and one of the senior midwives who have assisted in the birth of the twins says (9): "Ewe, ikhe yakho ingxumbungxumbu enjalo, besithi abanye ngulo omkhulu, besithi abanye ngulowa" ("Yes, there was such a disagreement, some saying the heir is this one and others saying it is that one.")

\section{Title of the novelette}

The title of Mqhayi's book bears the essence of what the Xhosa people perceive as the mechanism of justice. The Xhosa word ityala means "a lawsuit", and the term does not distinguish in this instance between a civil case and a criminal case. This is, therefore, a neutral term that in its detachment generates the quality of balance and even-handedness. If the writer had used the term ingxabano (a dispute), it would probably imply that both twins may to some degree be at fault, but what is likely to 
count in favour of one of them is the weight of argument he presents in court. As the title stands, it bears the principle that both the complainant and the defendant weigh evenly on the scale of justice and none of either of them is condemned before the trial. This is in agreement with the prevailing principle in the western system of justice, namely, that everybody is equal before the law, and that a person is innocent until s/ he is proven otherwise. Thus the universality of the principle borne by the Xhosa word ityala is evident. In fact it echoes Ngugi's comment about the universal being in the particular and vice versa.

\section{Xhosa court procedure}

The Xhosa system of justice is complete with court procedure, legal register and etiquette. John Solilo (Bennie 1935: 220-22) lists a selection of terms which he maintains are Xhosa legal terms. These include umSila weNgwe (a leopard's tail); isiGqeba (inner council); iNgximba (a rope); umBuliso (greeting). About umSila weNgwe Solilo gives the following explanation:

The Leopard's Tail represents the summons. [...] When someone has been charged a messenger is sent to plant it at the courtyard of the home that has been so charged. In the end someone will come across it even if it is a child. The person charged knows that it is his responsibility to pull it out and return it to the great place the following day. He knows that he has been summoned and cannot hold the court in contempt. This stick belongs to the great place and he will take it indoors. $^{1}$

The abovementioned procedure is an indication that court business is regarded as a serious matter among the Xhosa people. In this way Solilo easily associates this Xhosa traditional court procedure with the western court proceedings and translates umSila weNgwe as the summons (uyisamani). Right from the beginning of Mqhayi's story (1) we come across a carefully worded court dialogue which represents the initiation of the complainant's affidavit:

'I am filing a law suit!'

'Proceed!'

'I am filing a law suit against Babini!'

'Proceed!'

'Babini has erred against me!'

'Proceed!'

'Since we are such close relations, it so happened that he presumed to be the heir, and I presumed to be the heir.'

'Proceed!'

'While there is no outright head of the family, it is difficult to carry out the daily 
duties, because none of us wishes to stand back; we both claim to be senior.'

'Proceed!'

I felt that I should bring this issue here at home, so that it can be solved for us!'

'Proceed!'

'I stop so far, my lord!'

'Proceed - proceed! Mh-m-m! By the way! By the way! You say you are filing a

lawsuit?'2

Here Mqhayi is careful to represent the true circumstances experienced in a court case and succeeds in highlighting the technicalities of this court procedure. He cleverly refrains from analysing or attempting to explain the procedure. This, the reader ought to discover himself/herself. What is clear from this dialogue is the determination of the court official not to utter anything that will prejudice the case before it is even tried. The court official makes use of a neutral utterance in his manner of extracting the initial statement from the complainant. The utterance,' Hambisa! (proceed), remains non-committal and almost completely detached.

The complainant's language also remains unemotional and highly technical, and, on the surface of his speech, he keeps his distance by refraining from making a direct appeal for sympathy to the court official. He uses highly technical terms like Ndimangele, undixhomile and ukholosile. Normally, the term ukukholosa means 'to rely on', but in the context of Wele's statement it probably means 'he presumes to be the heir'. It would appear that by referring to the court as his home when he says, "Ndithi ke le nto mandiyizise koweth' apha, size kuyiconjululelwa!" he is in fact appealing for sympathy, but then he quickly covers that up by including his brother in his reference to home when he says, "size kuyiconjululelwa!" ("so that it can be solved for us.") Indeed the great place is regarded as the home of all Xhosa people and the king is seen as the father of the nation. Thus the Xhosa court differs from the western court which is seen as indifferent to the citizens in its application of justice. The latter does not mount to what a person can call home. During the trial Ndlombose, one of the court councillors confirms the idea of the king's court being home to his people when he says: "Akukho sifuna ukumona kwaba bantwana; ngabethu, siyabazala - siyabazala - siyabazala"(11). ("We do not wish to deal unfairly with any of these children; they are ours, we have born them - we have born them - we have born them.") Concerning the language and culture in Mqhayi's novelette, Gerard (1993: 78) observes:

The value of this short novel lies not so much in character depiction. Its real value lies in the magnificent exploitation of the intricacies of the Xhosa language. The writer reveals and reflects the cognitive orientation of the Xhosa, and this is done in grand style. In the course of this story, he also validates the cultural values of the Xhosa. 


\section{Position of the king as judge}

Mqhayi gives the impression of the Xhosa court as a place where one receives a fitting judgement and even punishment, which may be death for serious crimes, which is nevertheless a place of love and protection like a home. As a home the court cannot be said to be independent from the king. In his book, Chaka, Thomas Mofolo (1981: 5) tells the story of how Senzangakhona, king of the Fenulwenja tribe impregnates Nandi and then marries her to hide the scandal.

Mofolo states that the other girls had been told about the scandal, but, "when they heard of Senzangakhona's evil scheme" they could not tell "because a king, among the black people, is above the law." Still African thought goes further than that and sees law and justice as the Creator's tool for maintaining peace. The king is seen as the user of this tool; and when it is used wrongly it turns against him. So, in Mofolo's novel (1981:5) Senzangakhona transgresses by doing "an ugly deed that was against the law of nature and of man," and the birth and growth of Chaka serves as a punishment to him.

Dumisani, the king's poet in Ityala Lamawele observes in his poem after judgement has been given that:

In the olden days, the days when the mountains appeared,

One person was installed to rule the others.

It was then said that that person was of royal blood,

It was said that that person was the bullock of the nation,

It was said that that person must be obeyed by the people;

And he would then obey God;

From whom would come the laws and regulations,

Which would bring him trouble if he misused them,

There would be chaos and confusion among the people,

Chaos would take over and there would be madness on the land. (23). ${ }^{3}$

Dumisani's observation suggests that though the king is above the law by virtue of his being its custodian, he dares not break it for fear of bringing chaos to the land. God stands guard over him and sees to it that he receives a fitting punishment for his transgressions. It is perhaps for this reason that King Hintsa suspends judgement until he has made sure that every aspect of the case has been thoroughly investigated. Sityana (1978: 26) states that,

With some chiefs, if the chief happened to hate a certain individual, the people would also do the same, so much that if he declared that the person be killed no one would intervene, and they would just do what he wanted them to do. In court he would not utter a word, only his councillors would talk until they were in sight of the judgement. Then the chief councillor would lean forward to the chief to hear his decision on the business in hand. 
Depending on how he saw the matter as he sat quietly on his mat following the arguments of his men, he would tell the chief councillor what manner judgement would follow. In big, difficult court cases sentence was left to him to pass in person. ${ }^{4}$

As judge, King Hintsa, in Ityala Lamawele is thorough in his preliminary investigation and he allows his court a fair amount of time to deliberate and to question the witnesses. Khulile, the old man who is invited to give his professional opinion, represents a resource centre and as such his evidence brings about references to known cases. In the past, before the Xhosa people came into contact with the written word, old people were precious in society because they were the custodians of knowledge. Chapter 7 is titled, "Amava Enyange" ("Experience of the Man of Old"), and refers to the testimony of the old man, Khulile. Thus, as inyange, Khulile refers to a case from a generation of the remote past, namely, Nkosiyamntu versus Liwana (20). In this case Liwana had exchanged his position as heir for a piece of boys' meat. So the elders granted Nkosiyamntu, the younger twin brother, seniority.

When we look at the lineage of the Xhosa royal house we find that Khulile's reference transcends ten generations from Hintsa to Nkosiyamntu. The line of kings from Nkosiyamntu to Hintsa is as follows: Nkosiyamntu, Tshawe, Ngcwangu, Sikhomo, Togu, Ngconde, Tshiwo, Phalo, Gcaleka, Khawuta, then follows Hintsa the latter's son (Soga 1930: 80). The selection of this record does not only demonstrate the importance of Khulile as the repository of vital national data but also signals the significance of orality in Xhosa traditional life. The title of chapter 4, "Lisasiwe Kubahloli" ("It has been referred to the assessors"), reinforces the idea that for the success of this trial Khulile occupies a central position.

\section{Key principles governing the trial}

The trial itself is centred on three significant factors: the role of creation or nature; the rule of law, and the centrality of custom. As evidence is led one cannot help feeling that every one of the participants is in doubt about which of the three factors takes precedence, except perhaps the king who is the chief custodian of law and custom. Custom is man-made and is designed to secure good relations with the ancestors and Qamata. Law, as already indicated, is Qamata's own prescription to secure peace and order and is applied through a chosen individual, the king. Creation is a process that is controlled by Qamata Himself. Mqhayi cleverly hides from the characters the fact that law and custom take their cue from the process of creation. This device serves to mystify the readers until judgement is given. But before we analyse the king's judgement it is crucial first to identify what is perhaps Mqhayi's deliberate flaw in the trial, namely, the evidence of the senior midwives.

It is clear that the actions of Teyase, one of the senior midwives, cause the confusion 
that leads to the trial. In her evidence, Teyase says, "This woman experienced labour pains on Tuesday morning, [...] by sunrise one of the twins was already showing a hand. I just took a knife and cut the little finger." ${ }^{5}$ Where nature, law and custom can never go wrong, human ineptitude shows its head in the form of Teyase performing the custom prematurely. Teyase should be questioning the fact that a hand shows first and not the head of a baby. Instead of appreciating the dangerous situation that has developed, she panics, takes a knife and cuts a finger. A possible explanation of her action could be that she is inspired by the ancestors to do this, but no one thinks of asking her about her decision. That she performs a custom on a child whose face and body she cannot see and that she does this at a critical moment of birth are not explained in the trial. All we know is that, considering her estimated age, she is probably an expert at custom and could have given a fitting explanation for her actions. However, the writer withholds this from the readers in order to allow us to consider the mystery of custom and the wisdom of refraining from questioning the process of creation, here represented by birth. In their cross-examination of Teyase, none of the men queries the process of birth though there is evidently something unusual in the birth of these twins. Similarly, no one questions Teyase's actions because they hide behind the custom. By tradition men are not allowed in the hut where a baby is born. It follows, therefore, that the court councillors have no foreknowledge of what Teyase should have done. It complicates the case even more when evidence shows that no one has in fact broken the law. In that case both Wele and Babini are justified to claim seniority.

\section{Argument and interpretation of evidence}

The twins cannot themselves be questioned about their own birth and about the custom one of them receives at birth. But as adults and therefore active subjects of the law they can be held responsible for their actions. The king's judgement becomes fitting in that the twins are judged by their own interpretation of the circumstances of their birth.

Wele's argument is that he has received the custom first; his brother has exchanged seniority for a green bulbul; and Wele has been circumcised first. Regarding the actual birth, he maintains: "The crux of the matter is this, my lord, in my view you yourself, my lord, are not the one to pave the way for your councillor; it is the councillor who paves the way for you. Why should it be such an issue if my councillor paves the way for me?" (10). ${ }^{6}$ Wele's argument borders on the application of scientific justice, that is, justice that is reached through a mere observance of technicalities. The complainant argues like a lawyer who would like to see justice executed in his favour whatever the circumstances. When he compares his situation to a king whose councillor paves the way for him, we can sense that the truth is being forged to suit him, because a child being born cannot be compared to a king in any sense. The fact 
of being born first cannot be disputed, because it comes through a natural process, a process that not even a king can control. Khulile himself says "Why the heir is given to run the affairs of his home is because he has more experience by virtue of his having been born before his siblings" $(20)^{7}$. The amount of experience that comes with being born first is not measured. But, even here, the difference of a few hours in the birth of the twins renders being born first a mere technicality, as the senior twin surpasses the other by a negligible amount of time.

Nevertheless, the latter becomes Babini's argument, that as far as he knows he was born first and that fact is indisputable. Babini maintains:

The little I know is that I was conceived by a woman of the Mpandla clan and fathered by Vuyisile, my father. I am a twin, together with my younger brother who is suing me today. And those who helped my mother with our birth maintain that the first born is me; Wele followed after me. That was the understanding as we grew up. (6). ${ }^{8}$

Babini's argument pivots on the process of birth, a process from which law and custom take their cue. In fact, Babini does not set out to construct any suitable argument like his brother, but he simply states a known biological fact, without attempting to create any sensation. Babini is an interesting contrast to Clarence in Camara Laye's novel, The Radiance of the King (1956: 74-91). Clarence, the newcomer to the African system of justice is bewildered both by the register and the court procedure and ends up running in confused circles in the corridors of the palace of justice. On the contrary, Babini possesses an accurate interpretation of the court register which, as already discussed, does not question the performance of custom both in the cutting of his brother's finger and in the circumcision. He is comfortable with the fact that he cannot beg the law to give him what creation has already bestowed upon him as his birth right, namely, his seniority over his brother, Wele. In the wise words of the beggar in The Radiance (Laye 1956: 90): "[...] there is nothing to prevent my asking our host for a calabash of wine, but [...] I do not ask for it as if it were my 'right,' or even one of the simple rights of hospitality. You must understand that it is highly insulting, to ask for something that is one's 'right.'"

Mqhayi's aim here is to demonstrate expertise in the use of language in the Xhosa court of justice. The register is such that one can easily miss the excellence in Babini's language, thereby fallaciously concluding that Babini has no case. Wele is so confident about the relevance of his argument that when the king gives his judgement, he erroneously thinks that the judgement is in his favour and goes forward to kiss the king's foot. His problem rests in the fact that he believes in his rhetoric, which is styled on assembling relevant facts to fabricate the truth. The use of language and register by Mqhayi allows us more than one dimension from which to view the case. 


\section{The writer's intention}

There is the point of view and angle of the complainant who relies heavily on the eloquence of his solicitation. Then there is also the angle of the defendant who remains confident in the truthfulness of natural justice. Furthermore, there is the view of the reader, who may or may not be familiar with African thought and who may to some extent depend on what the characters say and do to make up his/her mind. On the other hand we have a knowledgeable reader who determines his/her verdict from the facts of the case without having to first look at what the characters think. Lastly, there is the angle of the writer himself. What does the writer intend to show us? Regarding the role of a writer Jafta (1978: 59) says: "The writer tries to give us the image of life as $\mathrm{s} /$ he sees it, and some even try to make us view life in the way they themselves perceive it." $^{\prime \prime}$

Mqhayi approaches the king's judgement in a similar manner, by encouraging us to see the judgement as he sees it. First of all he dwells on the general confusion which follows the judgement where men fight each other because they cannot come to an agreement on whose favour the judgement has fallen. It is as if the writer expects us, the readers, to be thrown into confused arguments and opposition resulting from our expectations which grow with the development of the plot. The core message of the king's sentence lies in the words directed at Babini thus: "You have heard, you first son of Vuyisile. You have heard the ups and downs of this court because of you; you have heard the words that have been directed to your younger brother by this court." $(22)^{10}$. In this manner the king shows caution not to violate the prescription laid down by the process of birth.

According to the judgement, Babini, who is the first to be born, is accorded his birth right as the senior son, and Wele is put in his place as the younger son. But the judgement accommodates natural talent that is the product of creation and associates the younger son with the management of the family's affairs, but this will be accomplished with the concurrence of the senior son. This judgement later leads Wele to admit that though he is the manager of his father's house, Babini is indeed the heir and final authority. But, contrary to expectations, Babini interprets the judgement in terms of the work done at home, whereupon, he assumes that as he is not so talented in home management, seniority must have been given to his brother by the king. We see in both of them the humility that is attributed to good leaders and people of authority. It is as a result of this humility that they later go to court each claiming the king's judgement had been in favour of the other and each stating that he expects the other to preside over the ukubuyisa ritual to be performed for their deceased father.

It is interesting that though the king is present when the court debates his judgement; no one asks or expects him to explain this. It is as though the moment of the utterance of the judgement has a kind of finality that cannot be reversed or revisited even by the king himself. He remains unquestioned, like nature which causes a hand 
to appear at birth, Teyase who performs custom upon an unborn child, and the operator during the circumcision of the twins who performs the operation on Wele first.

\section{Conclusion}

In conclusion Jafta (1978: 35) says: "A novel is the product of a variety of things in life. It sometimes happens that the writer has been inspired by the ups and downs of what he has experienced in his/her own life, and that shapes up the beginning for him/her. Another may yet be stimulated by the changing times, child delinquency and so on."11 Mqhayi claims that he wrote his novel as a result of his concern with the changing times. It seems to him that precious values of Xhosa life are lost in the pursuit of the western ways and style of life. In his introduction to the novel he observes: "The language and mode of life of the Xhosa people are gradually disappearing because of the Gospel and the new civilization, which came with the nations from the West." ${ }^{12}$ It is most probably for this reason that Mqhayi uses the trial as a vehicle to convey to us Xhosa (and therefore African) thought and way of life. What Jafta says about a writer can be exemplified by Mqhayi's intentions expressed in his introduction to Ityala Lamawele. The trial becomes a powerful and highly dramatic testimony of the beliefs and outlook of the Xhosa people more than it is just an exhibition of court procedure. Because of the richness of the language and the technical quality of the register both the emotive and the conceptual meanings are borne by the terse expressions that create a highly formal atmosphere. The expressions used are thus loaded with meaning.

\section{Notes}

1. UmSila weNgwe wona yisamani. [...] Xana kukho onetyala, kothunywa umntu aye kuwugxumeka enkundleni, kuloo mzi unetyala. Kodwa wogcina ukuba kubekho owubonayo, nokuba ngumntwana. Lowo unetyala uyazi ukuba yimfanelo yakhe ukuwuncothula, aye nawo komkhulu ngomso. Uyazi ukuba ubiziwe, engenakho ukwenza isidelo. Le ntonga yakomkhulu woyiphatha, aye nayo kokwabo kwakhe. (Solilo in Bennie 1935: 222). All translations from the original are mine.

2. 'Ndimangele!'

'Hambisa!'

'Ndimangalel' uBabini!'

'Hambisa!'

'UBabin' undixhomile!'

'Hambisa!'

'Sithe, kuba singabantu bezalana, wathi kanti ehleli nje yena ukholosile, ndathi kanti ndihleli nje nam ndikholosile.'

'Hambisa!'

'Ke kaloku ngoku angekhoyo umninimzi, yinkohla ukuhambisa micimbi yomzi, kuba akukho uvumayo ukubuya ngomva; sobabini sithi siziinkulu!"

'Hambisa!'

'Ndithi ke le nto mandiyizse koweth' apha, size kuyiconjululelwa!'

'Hambisa!' 
'Ndiyatshonela ke nkosi!' (1). Unless stated otherwise all quotations are from the referenced edition of Mqhayi's Ityala Lamawele and page references are cited parenthetically.

'Hambisa - hambisa! Mh-m-m! Gxebe! Gxebe! Uthi umangele?'

3. Ngemihla yakudala, mini kwavel' iintaba,

Kwabekw' umntu wamnye wokuphath' abanye.

Kwathiwa ke loo mntu ngumntu wegazi,

Kwathiwa loo mntu yinkonyana yohlanga,

Kwathiwa loo mntu makathotyelwe luluntu;

Aze athi yen' athobele uQamata;

Apho kuya kuvel' imithetho nezimiselo,

Aya kuth' akuzigwenxa, kungalungelelani,

Kube ziziphithiphithi nokuphambana koluntu,

Ibe nguqulukubhode ukuphambana komhlaba. (23).

4. Kwezinye iinkosi kwakusithi okokuba kuthe kwakho umntu emcaphukelayo inkosi nabantu [babe lapho] kangangokuba ukuba ithe makabulawe, kwakungekho unqandayo, kuphela kwakusenziwa loo nto iyifunayo. Ezinkundleni yayingavuli mlomo, kwakuthetha amadoda obuzwe bayo odwa de abone okokuba aya ekuphetheni. Liqale ngoko ithole logaga ukuthoba kuyo inkosi leyo lifuna uluvo lwayo kuloo mcimbi uphethweyo.

Apho iqonde khona yona, njengoko bekuxoxwa ithe cwaka, ihleli elugageni lwayo imamele, ilazise ithole logaga okokuba masiwe ngolu hlobo isigwebo. Kumatyala amakhulu anzima, kwakunikelwa kuyo iwise ngokwayo isigwebo ingathumeli. (Sityana 1978: 26).

5. Uyive lo mfazi inimba ngoLwesibini ekuseni, [...] lithe liphuma ilanga labe elinye iwele selivelise isandla. Ndafumana ndaqubula ingadla, ndawutsheca umnwe ucikicane. (9).

6. Le nto inje, nkosi, kokwam ukuthabathisa, wena lo, mhlekazi, asinguwe umntu wokugabulela umphakathi izigcawu; ngumphakathi into yokugabulela izigcawu. Kunani na, ukuba athi umphakathi wam akundigabulela izigcawu, kuxakeke kangaka? (10).

7. Inkulu le inikelwa ukuba iphathe umzi nje, kungenxa yokuba yona inamava okuvela tanci kunolunye usapho lwakowayo. (20).

8. Ntwana ndinenakani layo, yeyokuba ndizelwe ngubawo uVuyisile, ngenkazana yasemaMpandleni. Ndiliwele, ndiliwele nomninawa wam lo undinkqangisayo namhla. Baye besithi ke ababezalisa mna lowo, ivelatanci ndim; uWele sisizamva. Sikhula nje ke sikhula kuyiloo nto. (6).

9. Umbhali uzama ukusinika umfanekiso wobomi ngohlobo abubona ngalo yena, wumbi ude azame ukuba sibubone ubomi ngale ndlela athanda ukuba sibubone ngayo. (Jafta 1978: 59).

10. Uyeva ke mfo kaVuyisile omkhulu. Uwavile amasuka-ndihlale ale nkundla ngenxa yenu; ulivile ilizwi eliphathiswe umninawa wakho yile nkundla. (22).

11. Le nto iyinoveli izalwa zizinto ezininzi apha ebomini. Kuyenzeka ukuba umbhali achukunyiswe ngamanzithinzithi namahlandinyuka obomi athe wagqitha kuwo entlalweni yakhe, kanti kukulumeka kwesibane njalo. Wumbi uchukunyiswa kukujika kwamaxesha, intswelambeko ebantwaneni njalo njalo. (Jafta 1978: 35).

12. Intetho nemikhwa yesiXhosa iya itshona ngokutshona ngenxa yeLizwi nokhanyo olukhoyo, oluze nezizwe zaseNtshonalanga.

\section{Works cited}

Andrzejewski, B. W., S. Pilaszewicz and W. Tyloch. 1985. Literatures in African languages: Theoretical Issues and Sample Surveys. Warsaw: Wiedza Powszechna State Publishing House.

Bennie, W.G. 1935. Imibengo. Lovedale: The Lovedale Press.

Camara Laye. 1956. The Radiance of the King. Glasgow: William Collins \& Sons Co.

Dalthone, O. R. 1974/1975. African Literature in the Twentieth Century. Minneapolis: University of Minnesota Press.

Ityala-lamawele. [O]. Encyclopaedia Britannica Online. <www.britannica.com/EBchecked/topic/298093/ Ityala-lamawele> Accessed: 1.07.2009.

Jafta, D. N. 1978. Inoveli. In L. M. Mbadi and C. Z. Gebeda (eds.). Isisele. Lovedale: The Lovedale Press, 35-39. 
Jones, E. D. and M. Jones. 2002. South \& Southern African Literature: A Review. Oxford: James Currey. Mofolo, Thomas. 1981. Chaka. London: Heinemann Educational Books.

Mqhayi, S. E. K. 1970. Ityala lamawele. Lovedale: The Lovedale Press.

Neethling, B. \& N. Mpolweni. 2006. S. E. K.Mqhayi: Forerunner to democratic South Africa. South African Journal of African Languages, 26(3): 131-40.

Ngũgi wa Thiong'o. 1993. Moving the Centre. The Struggle for Cultural Freedoms. London: James Curry. Ntuli, D. B. and C.F. Swanepoel. 1993. Southern African Literature in African Languages: A Concise Historical Perspective. Goodwood: Acacia Books.

Sityana, A. M. 1978. Izixingaxi zamaXhosa. Umtata: Shuter \& Shooter.

Soga, J.H. 1930. The South-Eastern Bantu (Abe-Nguni, Aba-Mbo, Ama-Lala). Johannesburg: Witwatersrand University Press. 